\title{
Uji efektivitas kombinasi pupuk bio-slurry dengan pupuk npk terhadap pertumbuhan dan produksi dua varietas padi sawah (oryza sativa $L$.)
}

\section{(The effectiveness of combination of bio-slruyy and NPK fertilizer on the growth and yield of two varieties of rice (Oryza sativa L.))}

\author{
A. Khanafi, Yafizham, dan D.W. Widjajanto \\ Agroecotechnology, Department of Agriculture, Faculty of Animal and Agricultural Sciences, \\ Diponegoro University \\ Tembalang Campus, Semarang 50275 - Indonesia \\ CorrespondingE-mail:hanafiahmad52@gmail.com
}

\begin{abstract}
The objective of this research was to investigate the effectiveness of combination of bio-slurry fertilizer and NPK fertilizer on the growth and production of two varieties of rice. The experiment was assigned in a completely randomized design of factorial pattern. The first factor was the combination of bio-slurry and NPK fertilizer that consisted of $\mathrm{P}_{0}=$ no added fertilizer (control) 0 ton/ha, $\mathrm{P}_{1}=\mathrm{NPK}$ fertilizer $550 \mathrm{~kg} / \mathrm{ha}(165 \mathrm{~kg} \mathrm{~N}, 33 \mathrm{~kg} \mathrm{P}, 45 \mathrm{~kg} \mathrm{~K}) ; \mathrm{P}_{2}=$ bio-slurry fertilizer 2.3 tons $/ \mathrm{ha}$ ( $45 \mathrm{~kg} \mathrm{~N}, 14 \mathrm{~kg} \mathrm{P}$, $23 \mathrm{~kg} \mathrm{~K})$ and NPK fertilizer $400 \mathrm{~kg} / \mathrm{ha}(120 \mathrm{~kg} \mathrm{~N}, 24 \mathrm{~kg} \mathrm{P}, 32 \mathrm{~kg} \mathrm{~K}) ; \mathrm{P}_{3}=$ bio-slurry fertilizer 4.6 tons/ha $(90 \mathrm{~kg} \mathrm{~N}, 28 \mathrm{~kg} \mathrm{P}, 46 \mathrm{~kg} \mathrm{~K})$ and NPK fertilizer $250 \mathrm{~kg} / \mathrm{ha}(75 \mathrm{~kg} \mathrm{~N}, 15 \mathrm{~kg} \mathrm{P}, 20 \mathrm{~kg} \mathrm{~K}) ; \mathrm{P}_{4}=$ bio-slurry fertilizer 5.9 tons/ha $(115 \mathrm{~kg} \mathrm{~N}, 36 \mathrm{~kg} \mathrm{P}, 59 \mathrm{~kg} \mathrm{~K})$ and NPK fertilizer $100 \mathrm{~kg} / \mathrm{ha}(30 \mathrm{~kg} \mathrm{~N}, 6 \mathrm{~kg} \mathrm{P}, 8 \mathrm{~kg}$ $\mathrm{K})$; and $\mathrm{P}_{5}=$ bio-slurry fertilizer 8.5 tons $/ \mathrm{ha}(165 \mathrm{~kg} \mathrm{~N}, 52 \mathrm{~kg} \mathrm{P}, 85 \mathrm{~kg} \mathrm{~K})$. The second factor was varieties of rice that consisted of $\mathrm{V}_{1}$ : IR-64 and $\mathrm{V}_{2}$ : Ciherang. Each treatment was repeated three times. Parameters observed were plant height, number of tillers, weight of 1.000 grains, and rice production. Data were analyzed using ANOVA and continued with Duncan's Multiple Range Test (DMRT). The results showed that the combination of bio-slurry fertilizer and NPK fertilizer were significantly affect ( $p$ $<0.05$ ) all observation parameters, while varieties of wetland rice did not show significant effect on all observation parameters $(\mathrm{p}<0.05)$. The application of bio-slurry fertilizer in single treatment or in either combination with NPK fertilizer had the same result with the treatment of NPK fertilizer on the growth and yield of rice.
\end{abstract}

Keywords: rice, fertilizer combination, bio-slurry fertilizer, NPK fertilizer

\section{ABSTRAK}

Penelitian bertujuan untuk mengkaji efektivitas kombinasi pupuk bio-slurry dengan pupuk NPK terhadap pertumbuhan dan produksi dua varietas padi sawah. Penelitian menggunakan rancangan dasar acak lengkap pola faktorial, dengan perlakuan kombinasi pupuk bio-slurry dengan pupuk NPK, $\mathrm{P}_{0}$ : Tanpa pupuk (kontrol) 0 ton/ha; $\mathrm{P}_{1}$ : pupuk NPK $550 \mathrm{~kg} / \mathrm{ha}(165 \mathrm{~kg} \mathrm{~N}, 33 \mathrm{~kg} \mathrm{P}, 45 \mathrm{~kg} \mathrm{~K}) ; \mathrm{P}_{2}$ : Pupuk bioslurry 2,3 ton/ha (45 kg N, $14 \mathrm{~kg} \mathrm{P,} 23 \mathrm{~kg} \mathrm{~K})$ dan pupuk NPK $400 \mathrm{~kg} / \mathrm{ha}(120 \mathrm{~kg} \mathrm{~N}, 24 \mathrm{~kg} \mathrm{P}, 32 \mathrm{~kg} \mathrm{~K}) ; \mathrm{P}_{3}$ $=$ Pupuk bio-slurry 4,6 ton/ha (90 kg N, $28 \mathrm{~kg} \mathrm{P,} 46 \mathrm{~kg} \mathrm{~K})$ dan pupuk NPK $250 \mathrm{~kg} / \mathrm{ha}(75 \mathrm{~kg} \mathrm{~N}, 15 \mathrm{~kg} \mathrm{P}$, $20 \mathrm{~kg} \mathrm{~K}) ; \mathrm{P}_{4}$ : Pupuk bio-slurry 5,9 ton/ha (115 kg N, $\left.36 \mathrm{~kg} \mathrm{P,} 59 \mathrm{~kg} \mathrm{~K}\right)$ dan pupuk NPK $100 \mathrm{~kg} / \mathrm{ha}$ (30 $\mathrm{kg} \mathrm{N}, 6 \mathrm{~kg} \mathrm{P}, 8 \mathrm{~kg} \mathrm{~K})$; dan $\mathrm{P}_{5}$ : Pupuk bio-slurry 8,5 ton/ha (165 kg N, $\left.52 \mathrm{~kg} \mathrm{P,} 85 \mathrm{~kg} \mathrm{~K}\right)$ sebagai faktor pertama dan perlakuan varietas padi sawah, $\mathrm{V}_{1}$ : IR-64 dan $\mathrm{V}_{2}$ : Ciherang sebagai faktor kedua. Masingmasing perlakuan diulang sebanyak tiga kali. Parameter yang diamati adalah tinggi tanaman, jumlah anakan, bobot 1.000 gabah, dan produksi padi. Data dianalisis menggunakan analisis ragam dan dilanjutkan dengan Duncan's Multiple Range Test (DMRT). Hasil penelitian menunjukkan bahwa perlakuan kombinasi pupuk bio-slurry dengan pupuk NPK memberikan pengaruh nyata $(\mathrm{p}<0,05)$ terhadap semua parameter pengamatan, sedangkan untuk perlakuan varietas padi sawah tidak 
memberikan pengaruh nyata $(\mathrm{p}<0,05)$ terhadap semua parameter pengamatan. Aplikasi pupuk bio-slurry secara kombinasi maupun tunggal memiliki hasil yang sama dengan perlakuan pupuk NPK terhadap pertumbuhan dan produksi tanaman padi.

Kata kunci: padi sawah, kombinasi pupuk, pupuk bio-slurry, pupuk NPK

\section{PENDAHULUAN}

Padi merupakan tanaman pangan berupa rumput berumpun yang berasal dari dua benua, yaitu Asia dan Afrika Barat tropis dan subtropis. Tanaman padi mempunyai kemampuan beradaptasi hampir pada semua lingkungan dari dataran rendah sampai dataran tinggi (2000 $\mathrm{mdpl})$, dari daerah tropis sampai subtropis, dari daerah basah (rawa-rawa) sampai daerah kering (padang pasir), dari daerah subur sampai daerah marjinal (cekaman salinitas, aluminium, fero, dan lain-lain) (Utama, 2015).

Penggunaan pupuk anorganik terus-menerus tanpa disertai aplikasi pupuk organik dapat menyebabkan ketidakseimbangan unsur hara dalam tanah, rendahnya efisiensi pemupukan, rusaknya struktur tanah dan rendahnya mikrobiologi tanah berakibat pada menurunnya produksi tanaman. Oleh karena itu perlu adanya usaha perbaikan lahan dengan penambahan bahan organik (BO) kedalam lahan sawah. Berbagai
Bio-slurry sebagai pupuk organik telah banyak digunakan di areal pertanian di Indonesia untuk komoditi sayur-sayuran daun dan buah (cabai, labu siam, mentimun, tomat), umbi (kentang, wortel), buah-buahan (mangga, klengkeng, buah naga, pepaya, jeruk, pisang), tanaman pangan (jangung, padi, singkong) dan tanaman lain (coklat, kopi, kelapa) (Hartanto dan Putri, 2013).

Pupuk bio-slurry belum banyak dipergunakan dalam perbaikan lahan padi sawah di Indonesia, tetapi pupuk bio-slurry dipergunakan sebagai sumber BO dalam memperbaiki lahan sawah di beberapa negara. Pupuk bio-slurry mampu meningkatkan produksi tanaman padi mencapai $23 \%$ dibanding pemberian pupuk anorganik yang mengandung $\mathrm{N}, \mathrm{P}$ dan $\mathrm{K}$ (Gnanamani dan Bai, 1992). Aplikasi pupuk bioslury memiliki hasil yang sama dengan pupuk urea $100 \%$ dalam produksi tanaman padi (Bharde dkk., 2003). Penyerapan $\mathrm{N}$ oleh tanaman padi akibat aplikasi pupuk bio-slurry lebih rendah dibanding dengan aplikasi pupuk sintesis yang

Tabel 1. Hasil Analisis Tanah dan Pupuk Bio-slurry

\begin{tabular}{|c|c|c|c|c|c|}
\hline \multirow{3}{*}{ Media } & \multicolumn{5}{|c|}{ Kandungan Unsur Hara } \\
\hline & $\mathrm{N}$ & $\mathrm{P}$ & $\mathrm{K}$ & $\mathrm{C}$ & Rasio $\mathrm{C} / \mathrm{N}$ \\
\hline & \multicolumn{5}{|c|}{ 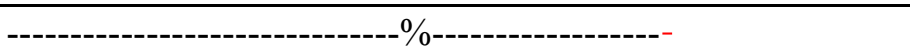 } \\
\hline Tanah & 0,2 & 0,09 & 1,60 & 2,44 & 11,62 \\
\hline Pupuk Bio-slurry & 1,95 & 0,61 & 1,00 & 24,05 & 12,33 \\
\hline
\end{tabular}

Keterangan : Analisis unsur hara tanah (N, P, K, dan C) dilaksanakan di Laboratorium Ekologi dan Produksi Tanaman, Fakultas Peternakan dan Pertanian, Universitas Diponegoro.

jenis BO seperti pupuk kandang, pupuk hijau, dan kompos sudah banyak dipergunakan dalam perbaikan lahan sawah.

Bio-slurry adalah campuran kotoran ternak padat dan cair sehingga memiliki tekstur lembek. Sebagai bahan organik bio-slurry diprediksi dapat dipergunakan untuk mengatasi ketidakberimbangan unsur hara di dalam tanah. mengandung NPK, tetapi produksi gabah tanaman padi yang memperoleh penambahan pupuk bioslurry tidak berbeda nyata dengan penggunaan pupuk sintetis (Ghoneim, 2008). Aplikasi pupuk bio-slurry yang dikombinasikan dengan pupuk sintetis $\mathrm{N}, \mathrm{P}, \mathrm{K}$ mampu meningkatkan produksi padi di wilayah India hingga 52\% dibanding dengan aplikasi pupuk sintetis atau bio-slurry 
yang terpisah (Gnanamani dan Bai, 1992).

Bio-slurry merupakan produk akhir pengolahan limbah ternak yang berbentuk lumpur yang sangat bermanfaat sebagai sumber nutrisi untuk tanaman. Nutrisi yang terkandung didalam pupuk bio-slurry diantaranya nutrisi makro yang dibutuhkan tanaman dalam jumlah yang banyak seperti nitrogen (N) 1,39-2,05\%, Phospor (P) 0,24-2,70\%, Kalium (K) 0,02-0,58\%, Kalsium (Ca) 13.934-28.300 ppm, Magnesium (Mg) 800$6421 \mathrm{ppm}$, dan Sulfur (S) 1,74\%, serta nutrisi mikro yang hanya diperlukan dalam jumlah sedikit seperti Ferum (Fe) 3,15 ppm, Mangan (Mn) 132,50-1.905 ppm, Tembaga (Cu) 9-36,23 ppm, dan Zeng (Zn) 40-97,11 ppm (Hartanto dan Putri, 2013). Bio-slurry juga mengandung asam amino, nutrisi mikro, vitamin $\mathrm{B}$, macam-macam enzim hidrolase, asam organik, hormon tanaman, antibiotik dan asam humat (Novira dkk., 2015). Pengaplikasian pupuk bio-slurry juga perlu dilengkapi dengan pupuk an-organik, hal ini dikarenakan pemberian pupuk organik saja dalam jangka pendek belum mampu memenuhi kebutuhan hara tanaman, karena perlu mengalami proses dekomposisi terlebih dahulu agar dapat diserap oleh tanaman (Leomo dkk., 2012).

Penelitian bertujuan untuk mengetahui efektivitas kombinasi pupuk bio-slurry dengan pupuk NPK terhadap pertumbuhan dan produksi dua varietas padi sawah.

\section{MATERI DAN METODE}

\section{Materi}

Penelitian lapang dilaksanakan pada tanggal 28 Maret - 19 Juli 2017 di lahan persawahan Dusun Grogol, Desa Wonosalam, Kecamatan Wonosalam, Kabupaten Demak (06 43'26"0709'48'LS; $\quad 110^{\circ} 27^{\prime} 58^{\circ}$ '-110 48'47'BT), Provinsi Jawa Tengah. Analisis kimia dan fisika dilakukan di Laboratorium Ekologi dan Produksi Tanaman, Departemen Pertanian, Fakultas Peternakan dan Pertanian, Universitas Diponegoro, Semarang (06 55'34"-07 07'04'LS; $110^{\circ} 16^{\prime} 20^{\prime \prime}-110^{\circ} 30^{\prime} 29^{\prime \prime}$ BT). Di wilayah penelitian memiliki suhu harian antara $23-34^{\circ} \mathrm{C}$, dengan curah hujan 101-3.000 mm/tahun (Badan Pusat Statistik Kabupaten Demak, 2016). Materi yang digunakan antara lain tanah sawah (mengandung $0,21 \% \mathrm{~N}, 0,9 \% \mathrm{P}, 1,6 \% \mathrm{~K}, 2,44 \% \mathrm{C}$-Organik, dan rasio $\mathrm{C} / \mathrm{N} 11,62)$ (Tabel 1), benih padi varietas IR64 dan Ciherang, pupuk bio-slurry (mengandung $1,95 \% \mathrm{~N}, 0,61 \% \mathrm{P}, 1,00 \% \mathrm{~K}, 24,05 \%$ C-Organik, dan rasio C/N 12,33) (Tabel 1), pupuk NPK 30-68, pupuk SP36 dan pupuk KCl.

\section{Metode}

Penelitian dilakukan dengan persiapan bahan, pengolahan lahan untuk bibit, persiapan bibit, persiapan media tanam, penanaman, pemupukan, perawatan, pengamatan parameter pertumbuhan, panen, dan pengamatan parameter produksi. Pengolahan lahan untuk pesemaian benih dilakukan dengan mencangkul tanah, membuat petak berukuran $2 \times 3$ meter dan diberi pupuk kandang kambing sebanyak $10 \mathrm{~kg}$. Persiapan bibit dilakukan dengan merendam benih

Tabel 2. Tinggi Tanaman Padi Akibat Perlakuan Kombinasi Pupuk Bio-slurry dengan Pupuk NPK dan Varietas Padi Sawah

\begin{tabular}{lccc}
\hline \hline \multicolumn{1}{c}{ Kombinasi Pupuk } & \multicolumn{2}{c}{ Varietas Padi } & \multirow{2}{*}{ Rerata } \\
\cline { 2 - 3 } & IR-64 & Ciherang & \\
\hline & $-65,01$ & 74,23 & $69,62 \mathrm{~b}$ \\
Tanpa Pupuk 0 kg/ha (P0) & 77,24 & 74,53 & $75,89 \mathrm{a}$ \\
Pupuk NPK 550 kg/ha (P1) & 72,67 & 76,50 & $74,58 \mathrm{a}$ \\
Pupuk bio-slurry 2,3 ton/ha dan pupuk NPK 400 kg/ha (P2) & 74,76 & 73,35 & $74,05 \mathrm{a}$ \\
Pupuk bio-slurry 4,6 ton/ha dan pupuk NPK 250 kg/ha (P3) & 74,39 & 75,18 & $74,79 \mathrm{a}$ \\
Pupuk bio-slurry 5,9 ton/ha dan pupuk NPK 100 kg/ha (P4) & 72,76 & 72,58 & $72,67 \mathrm{ab}$ \\
\hline Pupuk bio-slurry 8,5 ton/ha (P5) & 72,81 & 74,40 & \\
\hline \multicolumn{1}{c}{ Rerata } & & \\
\hline
\end{tabular}

Keterangan : Huruf yang berbeda pada kolom atau baris rerata menunjukkan berbeda nyata $(p<0,05)$. 
padi dalam air garam 3\% (30 g/liter) untuk memisahkan benih yang bernas (berisi) dengan benih yang hampa. Benih padi direndam dalam air selama $2 \times 24$ jam kemudian diperam dalam karung basah selama 2 hari hingga berkecambah. Benih disemaikan dengan cara ditabur pada lahan persemaian yang telah disiapkan sampai berumur 15 hari. Persiapan media tanam dilakukan dengan mengambil tanah dari lahan sawah dan ditimbang seberat $8 \mathrm{~kg} /$ pot. Tanah diberi pupuk bio-slurry sesuai dengan perlakuan. Penanaman dilakukan dengan menanam bibit padi berumur 15 hari setelah semai (HSS), sebanyak 3 bibit per pot. Pot yang telah ditanami bibit kemudian diatur dengan jarak tanam $20 \mathrm{~cm}$ x $20 \mathrm{~cm}$. Pemupukan dilakukan sesuai dengan dosis dan umur tanaman padi. Tanaman padi umur 7 hari setelah tanam (HST) diberikan 1/3 dosis pupuk NPK, $100 \%$ dosis pupuk SP-36 dan $100 \%$ dosis pupuk $\mathrm{KCl}$ sebagai pupuk dasar. Tanaman padi umur 20 HST diberikan 1/3 dosis pupuk NPK sebagai pupuk susulan I, dan tanaman padi umur 60 HST saat primordia (mulai berbunga) diberikan $1 / 3$ dosis pupuk NPK sebagai pupuk susulan II. Perawatan dengan melakukan penyiangan gulma yang tumbuh disekitar tanaman dengan cara manual dan pengendalian hama tanaman menggunakan pestisida. Panen dilakukan pada minggu ke-14 setelah tanam.

Parameter yang diamati antara lain 1) tinggi tanaman, 2) jumlah anakan, 3) Bobot 1.000 bulir padi dan 4) produksi padi. Parameter tinggi tanaman dan jumlah anakan dilakukan satu minggu sekali. Parameter bobot 1.000 gabah dan produksi padi dilakukan setelah panen dengan menimbang 1.000 gabah bernas.

\section{Rancangan Percobaan dan Analisis Data}

Rancangan yang digunakan dalam penelitian adalah Rancangan Acak Lengkap (RAL) pola faktorial $6 \times 2 \times 3$. Faktor I perlakuan pupuk yaitu $\mathrm{P}_{0}=$ Tanpa pupuk (kontrol) 0 ton/ha; $\mathrm{P}_{1}=$ pupuk NPK $550 \mathrm{~kg} / \mathrm{ha} ; \mathrm{P}_{2}=$ Pupuk bio-slurry 2,3 ton/ha dan pupuk NPK $400 \mathrm{~kg} / \mathrm{ha} ; \mathrm{P}_{3}=$ Pupuk bio-slurry 4,6 ton/ha dan pupuk NPK $250 \mathrm{~kg} / \mathrm{ha} ; \mathrm{P}_{4}=$ Pupuk bio-slurry 5,9 ton/ha dan pupuk NPK $100 \mathrm{~kg} / \mathrm{ha}$; dan $\mathrm{P}_{5}=$ Pupuk bio-slurry 8,5 ton/ha. Faktor II varietas padi sawah yaitu $V_{1}$ : Varietas IR-64 dan $\mathrm{V}_{2}$ : Padi varietas Ciherang. Analisis data dilakukan secara statistik berdasarkan prosedur analisis uji ANOVA. Uji lanjut terhadap perlakuan berpengaruh nyata terhadap paramater dilakukan menggunakan uji Duncan's Multiple Range Test (DMRT) taraf signifikasi 5\%.

\section{HASIL DAN PEMBAHASAN}

\section{Tinggi Tanaman}

Tinggi tanaman pada perlakuan kombinasi pupuk bio-slurry dengan pupuk NPK dan varietas padi sawah tersaji pada Tabel 2.

Parameter tinggi tanaman padi menunjukkan bahwa perlakuan pupuk NPK $550 \mathrm{~kg} / \mathrm{ha}$ memiliki rerata tinggi tanaman padi yang terbaik yaitu 75,89 cm. Pemberian pupuk an-organik NPK dapat meningkatkan pertumbuhan tanaman padi,

Tabel 3. Jumlah Anakan Padi Akibat Perlakuan Kombinasi Pupuk Bio-slurry dengan Pupuk NPK dan Varietas Padi Sawah

\begin{tabular}{lccc}
\hline \multicolumn{1}{c}{ Kombinasi Pupuk } & \multicolumn{2}{c}{ Varietas Padi } & \multirow{2}{*}{ Rerata } \\
\cline { 2 - 3 } & IR-64 & Ciherang & \\
\hline & --------- -anakan----------- \\
Tanpa Pupuk 0 kg/ha (P0) & 10,27 & 11,48 & $10,88 \mathrm{~b}$ \\
Pupuk NPK 550 kg/ha (P1) & 17,64 & 20,52 & $19,08 \mathrm{a}$ \\
Pupuk bio-slurry 2,3 ton/ha dan pupuk NPK 400 kg/ha (P2) & 17,15 & 20,12 & $18,64 \mathrm{a}$ \\
Pupuk bio-slurry 4,6 ton/ha dan pupuk NPK 250 kg/ha (P3) & 17,06 & 17,61 & $17,34 \mathrm{a}$ \\
Pupuk bio-slurry 5,9 ton/ha dan pupuk NPK 100 kg/ha (P4) & 17,91 & 16,73 & $17,32 \mathrm{a}$ \\
Pupuk bio-slurry 8,5 ton/ha (P5) & 16,70 & 13,61 & $15,15 \mathrm{ab}$ \\
\hline \multicolumn{1}{c}{ Rerata } & 16,12 & 13,61 & \\
\hline
\end{tabular}

Keterangan : Huruf yang berbeda pada kolom atau baris rerata menunjukkan berbeda nyata $(\mathrm{p}<0,05)$. 
hal ini dikarenakan sifat dari pupuk an-organik yang dapat langsung tersedia bagi tanaman, sehingga unsur hara yang terkandung dalam pupuk an-organik langsung dapat digunakan tanaman untuk menunjang pertumbuhan. Secara statistik perlakuan pupuk NPK $550 \mathrm{~kg} / \mathrm{ha}$ tidak berbeda nyata dengan perlakuan pupuk bio-slurry 2,3 ton/ha dan pupuk NPK $400 \mathrm{~kg} / \mathrm{ha}$, pupuk bioslurry 4,6 ton/ha dan pupuk NPK $250 \mathrm{~kg} / \mathrm{ha}$, pupuk bio-slurry 5,9 ton/ha dan pupuk NPK 100 $\mathrm{kg} / \mathrm{ha}$ dan pupuk bio-slurry 8,5 ton/ha. Hal ini menunjukkan bahwa perlakuan kombinasi pupuk bio-slurry dengan pupuk NPK dan perlakuan pupuk bio-slurry secara tunggal dapat menggantikan peran pupuk anorganik. Hal ini dikarenakan pupuk bio-slurry mampu meningkatkan kesuburan tanah, sehingga tanah dapat memenuhi kebutuhan unsur hara bagi tanaman. Hal ini sesuai dengan pendapat Groot dan Bogdanski (2013) bahwa bio-slurry bermanfaat dalam menyuburkan tanah pertanian karena dapat menetralkan asam dengan baik, menambahkan humus sebanyak $10-12 \%$ sehingga tanah lebih bernutrisi dan mendukung aktivitas perkembangan cacing dan mikroba tanah yang bermanfaat bagi tanaman. Hartanto dan Putri (2013) menambahkan bahwa pemakaian bioslurry dapat memperbaiki struktur fisik tanah sehingga tanah menjadi lebih gembur, meningkatkan kemampuan tanah mengikat atau menahan air lebih lama dan meningkatkan kesuburan tanah.

Sementara itu paramater tinggi tanaman pada kedua varietas padi yaitu IR-64 dan Ciherang tidak berbeda nyata, yaitu dapat dilihat pada Tabel 2 bahwa rerata tinggi tanaman padi varietas IR-64 $72,81 \mathrm{~cm}$ dan varietas Ciherang $74,40 \mathrm{~cm}$. Hal ini dikarenakan dalam deskripsi tanaman padi, varietas IR-64 memiliki tinggi tanaman yang hampir sama dengan varietas Ciherang, sehingga secara statistik tidak menunjukkan adanya perbedaan tinggi tanaman. Hal ini sesusi dengan pendapat Suprihatno dkk. (2010) bahwa tinggi tanaman padi varietas IR-64 rata-rata $115 \mathrm{~cm}$ sedangkan varietas Ciherang memiliki tinggi tanaman antara $107-115 \mathrm{~cm}$.

\section{Jumlah Anakan}

Jumlah anakan padi pada perlakuan kombinasi pupuk bio-slurry dengan pupuk NPK dan varietas padi sawah tersaji pada Tabel 3 . Jumlah anakan pada perlakuan pupuk NPK $550 \mathrm{~kg} / \mathrm{ha}$, pupuk bio-slurry 2,3 ton/ha dan pupuk NPK $400 \mathrm{~kg} / \mathrm{ha}$, pupuk bio-slurry 4,6 ton/ha dan pupuk NPK $250 \mathrm{~kg} / \mathrm{ha}$, Pupuk bio-slurry 5,9 ton/ha dan pupuk NPK $100 \mathrm{~kg} / \mathrm{ha}$, dan pupuk bioslurry 8,5 ton/ha berbeda nyata $(p<0,05)$ lebih tinggi dibanding dengan perlakuan tanpa pupuk (kontrol), sementara itu perlakuan pupuk NPK $550 \mathrm{~kg} / \mathrm{ha}$ tidak berbeda nyata dengan perlakuan pupuk bio-slurry 2,3 ton/ha dan pupuk NPK 400 $\mathrm{kg} / \mathrm{ha}$, pupuk bio-slurry 4,6 ton/ha dan pupuk NPK $250 \mathrm{~kg} / \mathrm{ha}$, Pupuk bio-slurry 5,9 ton/ha dan pupuk NPK $100 \mathrm{~kg} / \mathrm{ha}$, dan pupuk bio-slurry 8,5 ton/ha (Tabel 3). Hal ini menunjukkan bahwa penggunaan pupuk an-organik yang

Tabel 4. Bobot 1.000 Gabah Akibat Perlakuan Kombinasi Pupuk Bio-slurry dengan Pupuk NPK dan Varietas Padi Sawah

\begin{tabular}{|c|c|c|c|}
\hline \multirow{2}{*}{ Kombinasi Pupuk } & \multicolumn{2}{|c|}{ Varietas Padi } & \multirow{2}{*}{ Rerata } \\
\hline & IR-64 & Ciherang & \\
\hline & \multicolumn{3}{|c|}{-------------------g } \\
\hline Tanpa Pupuk 0 kg/ha (P0) & 15,63 & 19,36 & $17,50 \mathrm{~b}$ \\
\hline Pupuk NPK 550 kg/ha (P1) & 22,55 & 23,59 & $23,07 \mathrm{a}$ \\
\hline Pupuk bio-slurry 2,3 ton/ha dan pupuk NPK $400 \mathrm{~kg} / \mathrm{ha}(\mathrm{P} 2)$ & 23,44 & 22,99 & $23,22 \mathrm{a}$ \\
\hline Pupuk bio-slurry 4,6 ton/ha dan pupuk NPK $250 \mathrm{~kg} / \mathrm{ha}$ (P3) & 26,60 & 23,82 & $25,21 \mathrm{a}$ \\
\hline Pupuk bio-slurry 5,9 ton/ha dan pupuk NPK $100 \mathrm{~kg} / \mathrm{ha}$ (P4) & 24,84 & 24,70 & $24,77 \mathrm{a}$ \\
\hline Pupuk bio-slurry 8,5 ton/ha (P5) & 23,59 & 25,62 & $24,61 \mathrm{a}$ \\
\hline Rerata & 22,78 & 23,35 & \\
\hline
\end{tabular}

Keterangan : Huruf yang berbeda pada kolom atau baris rerata menunjukkan berbeda nyata $(\mathrm{p}<0,05)$. 
dikombinasikan dengan bio-slurry berpengaruh terhadap pertumbuhan padi IR-4 dan Ciherang terutama pada parameter jumlah anakan. Hal ini diduga karena pemberian bio-slurry mampu meningkatkan ketersediaan hara makro dan hara mikro yang dibutuhkan oleh tanaman.

Kombinasi pupuk an-organik dan bio-slurry mampu meningkatkan pertumbuhan tanaman disebabkan pada awal pertumbuhan terdapat unsur hara yang langsung dapat diserap oleh tanaman dari pupuk an-organik, sesuai dengan pendapat Leomo dkk. (2012) bahwa aplikasi pupuk anorganik dan pupuk organik secara bersamaan dapat meningkatkan pertumbuhan tanaman. Pupuk anorganik mengandung unsur hara yang langsung dapat diserap oleh tanaman, sedangkan peran rhizobakteri dalam pupuk organik sebagai dekomposer mulai aktif sehingga unsur hara lebih cepat tersedia bagi tanaman. Novira dkk. (2015) menambahkan bahwa pemberian pupuk bio-slurry perlu dilengkapi dengan pupuk anorganik, dikarenakan pemberian pupuk bio-slurry dalam jangka pendek belum mampu memenuhi kebutuhan hara tanaman, karena perlu mengalami proses dekomposisi terlebih dahulu agar dapat diserap oleh tanaman. Dalam penelitian ini menunjukkan bahwa perlakuan bio-slurry secara tunggal dan kombinasi dengan pupuk anorganik tidak menunjukkan jumlah anakan yang berbeda nyata, dan oleh karena itu bio-slurry dapat diimplementasikan secara tunggal tanpa menambahkan pupuk anorganik.

Perlakuan pupuk bio-slurry 8,5 ton/ha tidak berbeda nyata dengan perlakuan pupuk NPK 550 $\mathrm{kg} / \mathrm{ha}$, pupuk bio-slurry 2,3 ton/ha dan pupuk NPK $400 \mathrm{~kg} / \mathrm{ha}$, pupuk bio-slurry 4,6 ton/ha dan pupuk NPK $250 \mathrm{~kg} / \mathrm{ha}$, dan pupuk bio-slurry 5,9 ton/ha dan pupuk NPK $100 \mathrm{~kg} / \mathrm{ha}$. Hal ini menunjukkan bahwa aplikasi pupuk bio-slurry secara tunggal mampu menggantikan peran pupuk an-organik dalam meningkatkan pertumbuhan tanaman, karena bio-slurry mengandung nutrisi makro yang dibutuhkan tanaman dalam jumlah yang banyak seperti (Nitrogen, Fosfor dan Kalium) dan nutrisi mikro yang dibutuhkan tanaman dalam jumlah sedikit (Kalsium, Magnesium, Mangan, Ferum, dan Zeng). Selain itu bio-slurry mengandung mikroba pro-biotik yang membantu meningkatkan kesuburan tanah dengan menambah nutrisi didalam tanah. Hal ini sesuai dengan pendapat Haque (2013) yang menyatakan bahwa bio-slurry mengandung nutrisi makro N, P, K yang dibutuhkan tanaman dalam jumlah yang banyak. Selain nutrisi makro, bioslurry mengandung nutrisi mikro seperti $\mathrm{Zn}, \mathrm{Fe}$, $\mathrm{Mg}$, dan $\mathrm{Cu}$ yang penting untuk dalam mendukung pertumbuhan tanaman yang dibutuhkan dalam jumlah sedikit. Groot dan Bogdanski (2013) menambahkan bahwa bioslurry mengandung mikroba selulitik, mikroba penambat nitrogen, dan mikroba pelarut fosfat yang membantu menyuburkan tanah dan meningkatkan nutrisi tanah.

Paramater jumlah anakan pada kedua varietas padi yaitu IR-64 (16,2 anakan) dan Ciherang (13,61 anakan) tidak berbeda nyata, tidak sesuai dengan deskripsi tanaman padi (Tabel 3). Hal ini diduga kedua jenis padi memberikan respon yang tidak berbeda akibat perlakuan pemberian pupuk. Respon kedua jenis padi tidak sesuai dengan Suprihatno dkk. (2010) yang menemukan bahwa jumlah anakan padi varietas IR-64 antara 20-35 anakan dan varietas Ciherang antara 14-17 anakan. Jumlah anakan kedua varietas padi dalam penelitian ini dominan dipengaruhi faktor perlakuan dibanding faktor genetis, mengingat secara genetis kedua varietas padi semestinya memberikan respon yang berbeda. Hal ini sesuai dengan pendapat Dahlan dkk. (2012) bahwa keragaman akibat faktor lingkungan dan keragaman genetik umumnya berinteraksi satu sama lain dalam mempengaruhi penampilan fenotipe tanaman. Faktor genetik tidak akan memperlihatkan sifat yang dibawanya kecuali dengan adanya faktor lingkungan yang diperlukan. Sebaliknya, faktor lingkungan tidak akan menyebabkan perkembangan dari suatu sifat tanaman, jika faktor genetik yang diperlukan tidak terdapat pada tanaman.

\section{Bobot 1.000 Gabah}

Bobot 1.000 gabah pada perlakuan kombinasi pupuk bio-slurry dengan pupuk NPK dan varietas padi sawah tersaji pada Tabel 4 .

Hasil uji DMRT menunjukkan bahwa perlakuan pupuk NPK $550 \mathrm{~kg} / \mathrm{ha}$, pupuk bioslurry 2,3 ton/ha dan pupuk NPK $400 \mathrm{~kg} / \mathrm{ha}$, pupuk bio-slurry 4,6 ton/ha dan pupuk NPK 250 $\mathrm{kg} / \mathrm{ha}$, pupuk bio-slurry 5,9 ton/ha dan pupuk NPK $100 \mathrm{~kg} / \mathrm{ha}$, dan pupuk bio-slurry 8,5 ton/ha 
Tabel 5. Produksi Padi Pada Perlakuan Pupuk Tunggal Bio-Slurry, Pupuk Tunggal NPK, dan Kombinasi Pupuk Bio-Slurry dengan Pupuk NPK Serta Perlakukan Varietas Padi Sawah

\begin{tabular}{lccc}
\hline \hline \multirow{2}{*}{ Kombinasi Pupuk } & \multicolumn{2}{c}{ Varietas Padi } & \multirow{2}{*}{ Rerata } \\
\cline { 2 - 3 } & \multicolumn{1}{c}{ IR-64 } & Ciherang & \\
\hline & ---------- & ton/ha-------- \\
Tanpa Pupuk 0 kg/ha (P0) & 3,91 & 4,48 & $4,38 \mathrm{~b}$ \\
Pupuk NPK 550 kg/ha (P1) & 5,64 & 5,90 & $5,77 \mathrm{a}$ \\
Pupuk bio-slurry 2,3 ton/ha dan pupuk NPK 400 kg/ha (P2) & 5,86 & 5,75 & $5,80 \mathrm{a}$ \\
Pupuk bio-slurry 4,6 ton/ha dan pupuk NPK 250 kg/ha (P3) & 6,65 & 5,95 & $6,30 \mathrm{a}$ \\
Pupuk bio-slurry 5,9 ton/ha dan pupuk NPK 100 kg/ha (P4) & 6,21 & 6,18 & $6,20 \mathrm{a}$ \\
Pupuk bio-slurry 8,5 ton/ha (P5) & 5,90 & 6,41 & $6,16 \mathrm{a}$ \\
\hline \multicolumn{1}{c}{ Rerata } & 5,70 & 5,78 & \\
\hline
\end{tabular}

Keterangan : Huruf yang berbeda pada kolom atau baris rerata menunjukkan berbeda nyata $(\mathrm{p}<0,05)$.

berbeda nyata $(\mathrm{p}<0,05)$ lebih tinggi dibanding perlakuan tanpa pupuk (kontrol), sedangkan perlakuan pupuk NPK $550 \mathrm{~kg} / \mathrm{ha}$ tidak berbeda nyata terhadap perlakuan pupuk bio-slurry 2,3 ton/ha dan pupuk NPK $400 \mathrm{~kg} / \mathrm{ha}$, pupuk bioslurry 4,6 ton/ha dan pupuk NPK $250 \mathrm{~kg} / \mathrm{ha}$, pupuk bio-slurry 5,9 ton/ha dan pupuk NPK 100 $\mathrm{kg} / \mathrm{ha}$, dan pupuk bio-slurry 8,5 ton/ha (Tabel 4).

Hal ini menunjukkan bahwa aplikasi pupuk bio-slurry yang dikombinasikan dengan pupuk anorganik maupun aplikasi pupuk bio-slurry secara tunggal mampu memberikan hasil yang sama dengan aplikasi tunggal pupuk an-organik. Bioslurry mengandung nutrisi mikro, vitamin $\mathrm{B}$, asam organik, hormon pertumbuhan dan asam humat yang bermanfaat bagi pertumbuhan dan perkembangan tanaman. Hal ini sesuai dengan pendapat Hossaen dkk. (2011) bahwa pupuk bioslurry dapat memperbaiki kesuburan tanah, memperbaiki struktur tanah, dan meningkatkan aktivitas mikroorganisme didalam tanah, sehingga mampu meningkatkan peetumbuhan dan produksi tanaman. Rhaman dkk. (2016) menambahkan bahwa pertumbuhan tanaman lebih disebabkan oleh pertumbuhan dan perkembangan akar yang pesat akibat pemberian pupuk organik, karena pupuk organik dapat memperbaiki sifat fisik tanah dan meningkatkan ketersediaan unsur $\mathrm{N}, \mathrm{P}$ dan $\mathrm{K}$ dalam tanah.

Tanaman dalam menghasilkan gabah bernas yang menentukan bobot 1.000 gabah dipengaruhi oleh faktor genetik tanaman ketersediaan hara dan terjaminnya proses fisiologi tanaman. Hal ini sesuai dengan pendapat Padmanabha (2014) yang menyatakan bahwa unsur hara yang telah diserap oleh akar tanaman padi kemudian digunakan untuk pengisian biji sehingga jumlah gabah berisi lebih banyak dan berpengaruh terhadap meningkatnya bobot 1.000 gabah. Hardjadi (1991) menambahkan bahwa dengan meningkatnya asimilasi maka terjadi penumpukan karbohidrat yang disimpan dalam jaringan batang dan daun kemudian diubah menjadi gula, lalu diangkut ke jaringan biji sehingga dapat menambah berat biji.

Sementara itu paramater bobot 1.000 gabah pada kedua varietas padi yaitu IR-64 $(22,78 \mathrm{~g})$ dan Ciherang $(23,35 \mathrm{~g})$ tidak berbeda nyata, jika bobot 1.000 gabah kedua varietas padi dibandingkan dengan deskripsi tanaman padi, rerata tersebut masih tergolong rendah (Tabel 4). Seperti yang tertera pada Tabel 3 bahwa rerata jumlah anakan masih tergolong rendah, sehingga mempengaruhi bobot 1.000 gabah. Secara numerik bobot 1.000 gabah varietas Ciherang lebih tinggi dibandingkan dengan varietas IR-64. Menurut Suprihatno dkk. (2010) bobot 1.000 bulir padi varietas IR-64 24,1 $\mathrm{g}$ dan varietas Ciherang $28 \mathrm{~g}$. Produksi bulir padi berkaitan erat dengan jumlah anakan, jumlah malai, dan jumlah bulir padi bernas. Semakin banyak jumlah anakan, jumlah malai dan jumlah bulir padi bernas, maka semakin tinggi produksi bulir padi. Selain itu faktor lingkungan juga mempengaruhi hasil bobot 1000 gabah. Hal ini sesuai dengan pendapat Agustamar (2007) yang menyatakan bahwa jumlah anakan produktif merupakan peran utama dengan kontribusi 
terhadap hasil sebesar $48 \%$, jadi hampir setengah dari gabah kering giling (GKG) ditentukan oleh jumlah anakan produktif. Suryana (2008) menyatakan bahwa hasil bobot 1.000 gabah dipengarungi oleh lingkungan pada fase pematangan biji. Adiningsih (2005) menambahkan bahwa semakin banyak gabah yang terbentuk semakin tinggi beban tanaman untuk membentuk gabah yang berisi (bernas).

\section{Produksi Padi}

Produksi padi pada perlakuan pupuk tunggal bio-slurry, pupuk tunggal NPK, dan kombinasi pupuk bio-slurry dengan pupuk NPK serta perlakukan varietas padi sawah tersaji pada Tabel 5.

Hasil uji DMRT pada Tabel 5 menunjukkan bahwa perlakuan pupuk NPK $550 \mathrm{~kg} / \mathrm{ha}$, pupuk bio-slurry 2,3 ton/ha dan pupuk NPK $400 \mathrm{~kg} / \mathrm{ha}$, pupuk bio-slurry 4,6 ton/ha dan pupuk NPK 250 $\mathrm{kg} / \mathrm{ha}$, pupuk bio-slurry 5,9 ton/ha dan pupuk NPK $100 \mathrm{~kg} / \mathrm{ha}$, dan pupuk bio-slurry 8,5 ton/ha berbeda nyata $(p<0,05)$ lebih tinggi dibandingkan dengan perlakuan tanpa pupuk (kontrol), sedangkan perlakuan pupuk NPK $550 \mathrm{~kg} / \mathrm{ha}$ tidak berbeda nyata dengan perlakuan pupuk bio-slurry 2,3 ton/ha dan pupuk NPK $400 \mathrm{~kg} / \mathrm{ha}$, pupuk bioslurry 4,6 ton/ha dan pupuk NPK $250 \mathrm{~kg} / \mathrm{ha}$, pupuk bio-slurry 5,9 ton/ha dan pupuk NPK 100 $\mathrm{kg} / \mathrm{ha}$, dan pupuk bio-slurry 8,5 ton/ha. Hal ini menunjukkan bahwa penggunaan pupuk bioslurry secara kombinasi maupun tunggal mampu menghasilkan produksi gabah yang sama secara statistik dengan penggunaan pupuk an-organik. Hal ini sesuai dengan Garg dkk. (2005) bahwa aplikasi pupuk bio-slurry dapat meningkatkan indeks luas daun, kerapatan akar, tinggi tanaman, dan produksi tanaman padi. Basak dkk. (2016) menambahkan bahwa penggunaan bio-slurry yang dikombinasikan dengan pupuk an-organik mampu meningkatkan produksi tanaman padi.

Aplikasi tanpa pupuk (kontrol) menghasilkan produksi gabah paling rendah, hal tersebut dikarenakan tanaman padi mengalami defisiensi unsur hara. Unsur hara N, P, K secara tidak langsung berpengaruh terhadap fotosintesis. Unsur hara $\mathrm{N}$ berfungsi didalam meningkatkan kandungan klorofil, unsur $\mathrm{P}$ berperan dalam pembentukan sel dalam jaringan dan mempercepat proses pemasakan serta mendorong perkembangan gabah, dan unsur $\mathrm{K}$ diperlukan dalam pembentukan gula, zat tepung serta mengaktifkan berbagai macam enzim. Oleh karena itu, ketiga unsur N, P, K secara bersama-sama mempengaruhi fotosintesis, dan menentukan hasil gabah. Sonbai dkk. (2013) menyatakan bahwa fungsi nitrogen sebagai pupuk adalah untuk memperbaiki pertumbuhan vegetatif tanaman (tanaman yang tumbuh pada tanah yang cukup nitrogen akan berwarna hijau) dan membantu proses pembentukan protein. Liferdi (2010) menyatakan bahwa unsur fosfor sangat berguna untuk pembentukan sel baru pada jaringan yang sedang tumbuh, merangsang pertumbuhan akar, bahan dasar protein, memperkuat batang tanaman serta membantu asimilasi dan respirasi. Taiz dan Ziger (2002) menambahkan bahwa unsur hara kalium berfungsi meningkatkan sintesis dan translokasi karbohidrat, sehingga mempercepat penebalan dinding-dinding sel dan ketegaran tangkai/buah/cabang.

Hasil uji DMRT menunjukkan bahwa perlakuan varietas IR-64 tidak berbeda nyata dengan varietas Ciherang. Produksi padi berkaitan dengan jumlah anakan, jumlah malai, dan bobot 1.000 gabah. Perlakuan varietas IR-64 dan Ciherang pada parameter jumlah anakan (Tabel 3), dan bobot 1.000 gabah (Tabel 4) menunjukkan hasil yang tidak berbeda nyata, sehingga mempengaruhi produksi gabah. Hal ini sesuai dengan pendapat Basak dkk. (2016) bahwa jumlah gabah per malai dan bobot 1.000 butir gabah mempunyai korelasi positif terhadap hasil gabah. Edi dkk. (2015) menambahkan bahwa pembentukan anakan produktif, jumlah malai, dan bobot 1.000 gabah sangat menentukan hasil gabah, semakin banyak jumlah anakan produktif, jumlah malai, dan bobot 1.000 gabah maka semakin tinggi hasil gabah per-hektarnya.

\section{KESIMPULAN}

Hasil penelitian menunjukkan bahwa bahwa perlakuan kombinasi pupuk bio-slurry dengan pupuk NPK memberikan pengaruh nyata $(\mathrm{p}<0,05)$ terhadap semua parameter pengamatan, sedangkan untuk perlakuan varietas padi tidak memberikan pengaruh nyata $(p<0,05)$ terhadap semua parameter pengamatan. Aplikasi pupuk bio-slurry secara tunggal maupun kombinasi dengan pupuk 
NPK memiliki hasil yang sama dengan perlakuan pupuk NPK secara tunggal terhadap pertumbuhan dan produksi tanaman padi. Hasil penelitian memberikan indikasi bahwa pupuk bio-slurry dapat menggantikan peran pupuk NPK pada pertanaman padi khususnya varietas IR-64 dan Ciherang yang dibudidayakan pada dataran rendah.

\section{DAFTAR PUSTAKA}

Adiningsih, S. 2005. Peranan bahan/pupuk organik dalam menunjang peningkatan produktivitas lahan pertanian. Proceeding Workshop Maporina. Hal 37-48. Jakarta 21 22 Desember.

Agustamar. 2007. Kajian prospek penerapan metode SRI (The System of Rice Intensification) pada sawah bukaan baru. Disertasi. Fakultas Pertanian Unand, Padang.

Badan Pusat Statistik Kabupaten Demak. 2016. Demak Dalam Angka. BPS Kabupaten Demak. 345 hal.

Basak, K.D., M.G. Kibiria, M. Hossain, and M.A. Hoque. 2016. Improvement of rice production through combined yse of organic manure and bio-slurries with chemical fertilizer. Asian Aust. J. Biotech., 1(1) : 7578.

Bharde, N.M., Y.S. Shivay, and S. Singh. 2003. Effect of bioslurry and neem oil-treated urea sources in rice (Oryza sativa) - wheat (Triticum aestivum) cropping system. Indian J. Agron., 48 (2) : 73-75.

Dahlan, D., Y. Musa., dan M. I. Ardah. 2012. Pertumbuhan dan produksi dua varietas padi sawah pada berbagai perlakuan rekomendasi pemupukan. J. Agrivor. 11(2) : 262-274.

Edi, S., Mildaerizanti, dan D. Nofrianti. 2015. Kajian pertumbuhan dan potensi hasil beberapa varietas lokal padi gogo tahan cekaman kekeringan. Prosiding seminar nasional lahan suboptimal 2015. Palembang
8-9 Oktober 2015. Balai Pengkajian Teknologi Pertanian (BPTP) Jambi. Hal . 110.

Garg, R.N., H. Pathak, D.K. Das, and R.K. Tomar. 2005. Use of fly ash and biogas slurry for improving wheat yield and physical properties of soil. Environ. Monit. Assess. $107: 1-9$.

Ghoneim, A.M. 2008. Nitrogen dynamics and fertilizer use efficiency in rice using the nitrogen-15 isotope technique. World Applied Sci. J., 3 (6) : 869-874.

Gnanamani, A., and K. Bai. 1992. Influence of biodigested slurry on rice-gram cultivation. Bioresources Tech., 4(1) : 217-221.

Groot, L.D., and A. Bogdanski. 2013. Bio-slurry brown gold: a review of scientific literature on the co-product. of biogas production. FAO-UN. Roma.

Hardjadi, M.S. 1991. Pengantar Agronomi. Gramedia, Jakarta.

Hartanto, Y., dan C.H, Putri. 2013. Pedoman Penggunaan dan Pengawasan, Pengelolaan dan Pemanfaatan Bio-slurry. Tim Biogas Rumah (BIRU), Yayasan Rumah Energi (YRE), Jakarta. 31 hal.

Haque, A. 2013. Bio slurry Ultimate Choice of Biofertilizer. Bangladesh Agric. Univ., 2: 738 doi: $10.4172 /$ scientificreports. 738 .

Hossaen, M.A., A.T.M Shamsuddoha, A.K. Paul, M.S.I. Bhuiyan, and A.S.M. Zobaer. 2011. Efficacy of different organic manures and inorganic fertilizer on the yield and yield attributes of boro rice. The Agriculturists. 9 : 117-125.

Liferdi, L. 2010. Efek pemberian fosfor terhadap pertumbuhan dan status hara pada bibit manggis. J. Hort., 20(1) : 18-26.

Leomo, S., G.A.K. Sutariati., dan Agustina. 2012. Uji kombinasi pupuk organik dan anorganik 
dalam pola leisa terhadap pertumbuhan dan hasil tanaman sorgum lokal pada lahan marginal. J. Agroteknos. 2 (3) : 166-174.

Novira, F., Husnayetti., dan S. Yoseva. 2015. Pemberian pupuk limbah cair biogas dan urea, tsp, kcl terhadap pertumbuhan dan produksi tanaman jagung manis (Zea mays sacsharata Sturt.). JOM Faperta 2 (1) : 1-15.

Padmanabha, I.G., I.D.M. Arthagama., dan I.N. Dibia. 2014. Pengaruh dosis pupuk organik dan anorganik terhadap hasil padi (Oryza sativa L.) dan sifat kimia tanah pada inceptisol kerambitan tabanan. E-Jurnal Agroekoteknologi Tropika 3 (1) : 41-50.

Rhaman, M.S., M.G. Kibria, M. Hossain, and M.A. Hoque. 2016. Effects of organic manure and bio-slurries with chemical fertilizers on growth and yield of rice (cv. BRRI dhan28). Int. J. Expt. Agric. 6 (3) : 3642.
Sonbai, J.H.H., D. Prajitno., dan A. Syukur. 2013. Pertumbuhan dan hasil jagung pada berbagai pemberian pupuk nitrogen di lahan kering regosol. Ilmu Pertanian 16 (1) : 77-89.

Suprihatno, B., A.A. Daradjat, Satoto, Baehaki, Suprihanto, A. Setyono., S.D. Indrasari, I.P. Wardana, dan H. Sembiring. 2010. Deskripsi Varietas Padi. Balai Besar Penelitian Tanaman Padi, Sukamandi. 105 hal.

Suryana, A. 2008. Pengelolaan Tanaman Terpadu (PTT) Padi Sawah Irigasi. Badan Penelitian dan Pengembangan Pertanian. Departemen Pertanian.

Taiz, L., and E. Zeiger. 2002. Plant physiology. Sinauer Associates, Inc., Publisher. Sunderland, Massachusetts.

Utama, M.Z.H. 2015. Budidaya Padi Pada Lahan Marginal. CV. Andi Offset, Yogyakarta. 